\title{
EKSISTENSI DESTINATION BRANDING DALAM UNDANG-UNDANG MEREK DAN INDIKASI GEOGRAFIS
}

\author{
Agus Adi Pranatha, Fakultas Hukum Universitas Udayana, E-mail: \\ agusap048@gmail.com \\ Ni Ketut Supasti Dharmawan, Fakultas Hukum Universitas Udayana, E-mail: \\ supasti_dharmawan@unud.ac.id \\ doi : https://doi.org/10.24843/ks.2020.v09.i01.p15
}

\begin{abstract}
ABSTRAK
Artikel ini bertujuan untuk menunjukkan eksistensi destination branding dalam peraturan tentang merek di Indonesia. Artikel ini menggunakan metode penelitian hukum normatif yang menekankan pembahasan pada pendekatan undang - undang. Dalam artikel ini penulis menggunakan sumber sumber berupa bahan hukum primer dan sekunder. Setelah melalui pembahasan dan analisis dapat dinyatakan bahwa, destination branding dapat diartikan sebagai upaya untuk memberikan sebuah ciri khas atau daya pembeda pada sebuah destinasi. Hingga saat ini memang belum ada pengaturan secara khusus yang menjelaskan tentang destination branding dalam undang - undang No. 20 tahun 2016 tentang Merek dan Indikasi Geografis, namun bukan berarti destination branding tidak dapat didaftarkan ke Direktorat Jenderal Kekayaan Intelektual, karena pada prinsipnya destination branding telah memenuhi unsur - unsur sebagai sebuah merek.
\end{abstract}

Kata Kunci: Merek, Destination Branding, Pendaftaran Merek

\begin{abstract}
This article aims to demonstrate the existence of destination branding in the regulation of brands in Indonesia. This article uses a normative legal research method that emphasizes the discussion of the legal approach. In this article, the author uses sources in the form of primary and secondary legal materials. After going through the discussion and analysis it can be stated that, destination branding can be interpreted as an effort to provide a distinctive feature or distinctive power to a destination. Until now, there is no specific regulation that explains destination branding in Law No. 20 of 2016 concerning Trademarks and Geographical Indications, but that does not mean that destination branding cannot be registered with the Directorate General of Intellectual Property, because in principle, destination branding fulfills the elements as a brand.
\end{abstract}

Key Word: Trade Mark, Destination Branding, Trademark Registration.

\section{Pendahuluan}

\subsection{Latar Belakang Masalah}

Kekayaan Intelektual atau yang selanjutnya disebut sebagai KI merupakan sebuah istilah yang digunakan atas beberapa jenis hak khusus yang diberikan atas hasil karya cipta manusia. Salah satu jenis KI yang paling sering kita gunakan adalah merek. Merek mempunyai sejarah yang cukup panjang. Diawali dengan perkembangan perdagangan pada abad pertengahan di negeri barat, dimana 
perdagangan antar negara mulai tumbuh dan berkembang. Diawal terwujudnya, merek memiliki fungsi sebagai penunjuk asal produk yang bersangkutan. Seiring dengan pesatnya perkembangan industri dan pasar, merek berfungsi sebagai apa yang kita kenal saat ini.

Menurut pendapat Sudargo Gautama, suatu merek dapat dimaknai sebagai penanda yang memiliki daya guna sebagai pembeda dari sebuah produk yang berasal dari suatu perusahaan dengan produk - produk dari perusahaan lain. ${ }^{1}$ Merek selalu diidentikkan dengan identitas bagi suatu produk yang dihasilkan oleh produsen, yang kemudian menjadi aset bagi produsen. ${ }^{2}$ Produk dalam hal ini tidak hanya berupa barang, melainkan juga jasa yang ditawarkan oleh para pengusaha. Dalam perkembangannya merek seakan menjadi suatu reputasi bagi barang dan jasa hasil usaha ketika diperdagangkan dipasaran.

Dalam Bahasa inggris merek dapat diartikan sebagai trademark atau brand. Seiring dengan pesatnya perkembangan zaman dan perkembangan ekonomi, saat ini merek menjadi sesuatu hal yang memperoleh perlindungan hukum. Di Indoensia sendiri perkembangan hukum merek sudah berlangsung sejak tahun 1912 yang pada saat itu tertuang dalam Reglement Industriele Eigendom Kolonien 1912, yang kemudian diperbarui dan dirubah dengan UU Nomor 21 tahun 1961 tentang Merek Perusahaan dan Merek Perniagaan. Yang kemudian diperbarui dan dirubah kembali dengan ditetapkannya UU nomor 19 Tahun 1992 tentang Merek. Pada prinsipnya dengan adanya perubahan tersebut, terjadi penyempurnaan peraturan terkait dengan perlindungan merek dan juga penyesuaian dengan Paris Convention. Namun undnag undang tersebut tidak dapat mengikuti perkembangan merek sehingga diadakan pembaruan kembali dengan ditetapkannya UU Nomor 14 tahun 1997, dan disempurnakan lagi menjadi UU Nomor 15 tahun 2001 tentang Merek, hingga pada akhirnya terbentuk UU Nomor 20 tahun 2016 tentang Merek dan Indikasi Geografis yang masih berlaku hingga saat ini.

Dalam UU Nomor 20 tahun 2016 tentang Merek dan Indikasi Geografis (yang selanjutnya disebut UU 20/2016), sebuah merek agar dapat memperoleh perlindungan hukum harus menjalani beberapa proses permohonan pendaftaran merek sebagaimana tertuang dalam BAB III, dan pendaftaran merek yang diatur dalam BAB IV, hingga pada akhirnya merek tersebut terdaftar. Seiring berjalannya waktu, istilah merek (trademark atau brand) menjadi umum dipakai dalam berbagai macam produk. Bahkan saat ini, sering kita dengar beberapa lokasi atau tempat memberikan sebuah pelebelan terhadap dirinya sendiri dengan harapan untuk meningkatkan daya tarik wisata di lokasi tersebut. Sebagai contoh, Indonesia dengan "Wonderfull Indonesia".

Pariwisata sendiri bukanlah suatu hal yang baru di Indonesia. Indonesia yang telah dijuluki sebagai surga dunia sejak dulu kala, tidak boleh mati langkah dalam menawarkan daya wisata yang dimilikinya. Dengan berdasarkan pada pasal 2 dan 3 UU Nomor 32 tahun 2004 tentang Pemerintah Daerah, yang mengisyaratkan bahwa pemerintah tingkat daerah diberikan kewenangan untuk mengelola sendiri potensi -

1 Fitrianigsi, Dewi. "Perlindungan Hukum Hak Atas Merek Perusahaan Yang Di Merger Menurut Konsepsi Undang-undang Nomor 15 Tahun 2001 Tentang Merek." PhD diss., Legal Opinion, Universitas Tadulako (2016): 4.

2 Qamar, Nurul, Muhammad Syarif, Dachran S. Busthami, M. Kamal Hidjaz, Aan Aswari, Hardianto Djanggih, and Farah Syah Rezah. Metode Penelitian Hukum (Legal Research Methods). CV. Social Politic Genius (SIGn), 2017, 29. 
potensi yang ada di daerah dengan berdasarkan pada asas otonomi. ${ }^{3}$ Ditambah dengan dikeluarkannya UU nomor 10 tahun 2009 tentang Kepariwisataan yang memberikan peluang kepada pemerintah daerah dalam melakukan pengembangan pariwisata. Hal tersebut menyebabkan berbagai daerah mulai giat untuk mengelola dan mengeksplorasi potensi yang dimiliki daerah dengan tetap memperhatikan hal - hal yang diatur dalam peraturan perundang - undangan. Dengan semakin pesatnya laju perkembangan dunia pariwisata, dalam beberapa tahun terakhir untuk mempermudah promosi wisata, beberapa obyek wisata melakukan branding untuk menarik minat berkunjung para wisatawan. Salah satu lokasi wisata yang menggunakan branding sebagai media untuk menunjukkan kualitasnya adalah adalah desa Kertha. Desa Kertha merupakan suatu wilayah yang berlokasi di Kecamatan Pangyangan, Kabupaten Gianyar, Provinsi Bali. Berdasarkan SK bupati Gianyar Nomor 429/E-02/HK/2017, desa kertha ditetapkan menjadi Desa Wisata. ${ }^{4}$ Adapun setelah ditetapkannya desa Kertha sebagai desa wisata, upaya selanjutnya yang dilakukan pemerintah adalah dengan melakukan branding terhadap desa Kertha guna menarik wisatawan dan investor sehingga mampu meningkatkan perekonomian masyarakat setempat. Upaya branding terhadap suatu obyek wisata ini sendiri kerap kita kenal dengan istilah destination brading.

Menurut Saxone Woon, brand bukan hanya sekedar nama, logo, maupun sebuah citra grafis. ${ }^{5}$ Ketika sebuah merek (trademark atau brand) dipadukan dengan sebuah obyek wisata, maka merek tersebut setidaknya dapat menggambarkan seperti apa kondisi, keadaan dan yang tak kalah pentingnya mengapa obyek wisata tersebut patut mendapat perhatian. Oleh karena itu destination branding dapat dikatakan sebagai sebagai media pemasaran bagi sebuah obyek wisata dalam membentuk karakteristik yang kuat sehingga obyek wisata tersebut menjadi lebih dikenal dan diminati oleh para wisatawan.

Eksistensi Destination Branding yang didasarkan pada UU 20/2016 adalah sesuatu yang sangat menarik untuk diulas lebih dalam. Melalui artikel ini, diharapkan dapat menjelaskan kedudukan destination branding dalam hukum merek di Indonesia. Hingga saati ini, penulis belum menemukan artikel maupun pembahasan yang secara spesifik menjelaskan tentang kedudukan destination branding dalam tatanan hukum merek di Indonesia saat ini. Eka Sita Michandani dalam artikel yang berjudul "Perancangan Destination Branding Desa Wisata Kerta Di Kecamatan Pangyangan Kabupaten Gianyar", hanya membahas seputar perancangan desain dari Destination Branding di Desa Kerta. Dalam undang - undang tersebut hingga saat ini memang belum terdapat penjelasan secara eksplisit tentang destination branding. Hal ini mengindikasikan adanya norma kabur dalam pengaturan mengenai destination branding. Hal ini yang kemudian mendasari penulis untuk mengulas lebih dalam

3 Rahman, Arif Faisal, dkk. "Aspek Hukum Regional Branding Dalam Undang - Undang Nomor 15 tahun 2001 Tentang Merek dan Undang - Undang Nomor 28 Tahun 2014 Tentang Hak Cipta (Studi Kasus Jogja Istimewa Sebagai Brand Daerah Istimewa Yogyakarta)". Jurnal Penelitian Hukum 2, No. 3 (2015): 179.

4 Michandani, Eka Sita. "Perancangan Destination Branding Desa Wisata Kerta Di Kecamatan Pangyangan Kabupaten Gianyar" Jurnal Destinasi Pariwisata, Fakultas Pariwisata, Universitas Udayana 7, No. 1 (2019): 111.

5 Fauzan, Siti Fridani. "City Branding Kota Bandung Melalui Bandung Tour On Bus (Studi Kasus: Badan Promosi Pariwisata Kota Bandung)". E Proceeding of Management 3. No. 1 (2016): 2 . 
tentang "Eksistensi Destination Branding Dalam Undang - Undang Merek dan Informasi Geografis".

\subsection{Rumusan Masalah}

Beranjak dari latar belakang tersebut, maka yang menjadi permasalahan yang menarik dalam tulisan ini adalah:

1. Apakah destination branding dapat dikategorikan sebagai sebuah hak merek menurut UU 20/2016?

2. Bagaimana cara pendaftaran destination branding sebagai sebuah merek?

\subsection{Tujuan Penulisan}

Berangkat dari isu tersebut, maka fokus tujuan dari artikel ini adalah untuk menunjukkan keberadaan atau eksistensi destination branding dalam hukum merek di Indonesia dan untuk menunjukkan potensi pendaftaran destination branding sebagai sebuah hak merek.

\section{Metode Penelitian}

Pada prinsipnya penelitian merupakan "suatu upaya pencarian". ${ }^{6}$ Menurut Sutrisno Hadi, "metode penelitian merupakan langkah - langkah yang wajib diambil dalam suatu penulisan secara sistematis dan logis, agar dapat dipertangungjawabkan kebenarannya." Dalam penulisan artikel ini, digunakan metode penelitian hukum normatif untuk mengungkap eksistensi destination branding dalam UU 20/2016. Pengumpulan bahan - bahan artikel dilakukan melalui penelusuran literatur, baik dalam bentuk buku - buku yang berkaitan dengan tema artikel maupun artikel ilmiah dalam media internet. Kemudian diolah dan dianalisis secara kualitatif, hingga pada akhirnya keseluruhan hasil artikel disajikan secara deskriptif dalam bentuk uraian naratif. ${ }^{7}$

\section{Hasil dan Pembahasan}

\subsection{Destination Branding Menurut Undang - Undang Merek dan Indikasi Geografis}

Merek memegang sebuah peranan yang besar dalam suatu pemasaran produk, dikarenakan sebuah merek mampu mempengaruhi daya jual dari suatu produk. Maka dari itu sudah sewajarnya apabila sebuah merek menjadi penting untuk dilindungi. Sejak awal berdirinya Negara Kesatuan Republik Indoensia hingga saat ini, pengaturan merek pertama kali tertuang dalam UU nomor 21 tahun 1961 tentang Merek Perusahaan dan Merek Perniagaan. ${ }^{8}$ Yang kemudian disempurnakan beberapakali hingga pada akhirnya terbentuk UU Nomor 20 tahun 2016 tentang Merek

6 Sugono, Bambang. Metodologi Penelitian Hukum, Edisi 1, Cet. XVI (Jakarta, PT Raja Grafindo Persada, 2015), 27.

7 Sudantra, I Ketut. "Implikasi Keputusan Meteri ATR/Kepala BPN Nomor 276/KEP19.2/X/2017 Terhadap Kedudukan Tanah Milik Desa Pakraman". Jurnal Magister Hukum Udayana (Udayana Master Law Hournal) 7, No.4 (2018): 549.

8 Yuli, Aditya. "City Branding Sebagai Strategi Pengembangan Pariwisata Ditinjau Dari Aspek Hukum Merek (Studi Kasus City Branding Daerah Istimewa Yogyakarta Sebagai Daerah Tujuan Wisata Unggulan Di Indonesia)". Jurnal Ilmiah Ilmu Hukum QISTI 5. No. 1 (2011): 54. 
dan Indikasi Geografis yang masih berlaku hingga saat ini. Pada prinsipnya dengan adanya perubahan tersebut, terjadi penyempurnaan peraturan terkait dengan perlindungan merek dan juga penyesuaian dengan berbagai instrument hukum.

Berbicara lebih lanjut mengenai merek, berdasarkan pasal 1 angka 1 UU 20/2016 yang menyatakan menyatakan bahwa:

"merek adalah tanda yang dapat ditampilkan secara grafis berupa gambar, logo, nama, kata huruf, angka, susunan warna, dalam bentuk 2 (dua) dimensi dan/atau 3 (tiga) dimensi, suara, hologram, atau kombinasi dari 2 (dua) atau lebih unsur tersebut untuk membedakan barang dan/atau jasa yang diproduksi oleh orang atau badan hukum dalam kegiatan perdagangan barang dan/atau jasa"

Secara singkat dalam Kamus Besar Bahasa Indonesia, merek dimaknai sebagai sebuah tanda pengenal yang dikenakan oleh pengusaha atas hasil produksi yang telah dihasilkan. ${ }^{9}$ Selain itu dalam pasal 15 ayat (1) TRIPs (Trade Related Aspects of Intelectual Rights) mengenai merek, menegaskan bahwa merek merupakan tanda maupun beberapa kombinasi taanda, yang mampu membedakan hasil produksi antar perusahaan. Berdasarkan beberapa definisi diatas, dapat dikatakan bahwa unsur dari sebuah merek terdiri dari, sebagai sebuah cap, tanda atau lambang, mempunyai fungsi sebagai daya pembeda atas suatu produksi barang atau jasa.

Daya pembeda yang dimaksud dalam hal ini adalah, kemampuan untuk membedakan atau membandingkan produk perusahaan A dengan perusahaan lainnya. Tidak terlalu rumit ataupun tidak terlalu sederhana hal itulah yang menjadi sebuah pedoman yang ideal bagi sebuah merek, selain itu perbedaan yang terdapat dalam sebuah merek baik secara pokok maupun keseluruhan merupakan suatu hal yang wajib dimiliki oleh suatu merek. ${ }^{10}$ Dengan kata lain, untuk dapat dikategorikan sebagai sebuah merek adalah apabila berfungsi sebagai pembeda, merupakan sebuah tanda atau cap atau lambang pada barang dagang atau jasa, dan bukan menjadi milik umum.

Selain itu menurut Rahmi Jened dalam bukunya menyatakan bahwa sebagai daya pembeda dalam suatu perdagangan barang maupun jasa, idealnya sebuah merek harus memiliki elemen tanda dengan daya pembeda, kemudian tanda tersebut harus digunakan untuk perdagangan barang dan jasa. ${ }^{11}$

Selama ini, hanya sedikit pengusaha yang menyadari bahwa membangun sebuah merek bukanlah suatu hal yang mudah. Dalam sebuah artikel Hermawan Kartajaya mengungkapkan bahwa sekalipun memiliki modal yang besar, apabila tidak dapat memanfaatkan dan menggunakan merek dengan baik, maka produk tersebut tidak akan dapat berkembang. Dalam hal ini dapat kita nyatakan bahwa apabila sebuah merek dapat dibangun dengan baik, maka dapat memperoleh keuntungan yang lebih besar.

Berdasarkan hal tersebut kita dapat melihat fungsi merek berdasarkan sudut pandang pelaku ekonomi, dimana bagi produsen merek dapat berfungsi sebagai penjamin nilai hasil serta kualitas produksinya. Selain itu merek juga digunakan sebagai daya pikat sebuah hasil produksi. Kemudian dari pihak pedagang, merek

9 Merek (Def. 1) (n.d). Dalam Kamus Besar Bahasa Indonesia (KBBI) Online. Diakses melalui kbbi.web.id/merek.html, 11 Juni 2020.

10 Harahap, Muhith Afif Syam. "Eksistensi City Branding Menurut UU No. 15 Tahun 2001 Tentang Merek (Studi Kasus "Semarang Pesona Asia" Di Kota Semarang)". Tesis Program Magister Ilmu Hukum, Universitas Diponegoro, Semarang. (2008): 74-75.

11 Jened, Rahmi, Interface Hukum Kekayaan Intelektual, and Hukum Persaingan. "RajaGrafindo Rajawali Press." (2013), 162. 
berfungsi sebagai media promosi dalam melakukan ekspansi usaha, sedangkan dari pihak konsumen, merek digunakan sebagai salah satu faktor dalam menentukan pilihan barang yang akan dibeli.

Sejalan dengan perkembangan teknologi, merek (brand atau trademark) ternama semakin menjadi ladang yang menjanjikan bagi para pengusaha. Namun sayangnya, hikmah tersebut bagai pedang bermata dua, disatu sisi memberikan keuntungan kepada pengusaha namun disisi lain merek yang terkenal menjadi sasaran bagi para pencuri atau pelanggar merek. Hal ini karena kesan dan predikat yang baik yang terdapat dalam sebuah merek ternama memberikan keuntungan kepada pemakainnya, hal ini menyebabkan para pengusaha pelanggar merek tidak segan - segan untuk memalsukan dan mendompleng reputasi dari merek terkenal untuk meraup keuntungan pribadi. Oleh karena itu pengaturan tentang merek ini menjadi poin penting bagi pelaku perekonomian. Di Indonesia sendiri, saat ini telah memiliki UU 20/2016 yang menjadi payung hukum terhadap perlindungan merek. Undang undang tersebut memberikan pengertian dan membagi merek menjadi beberapa jenis, yaitu:

Dalam Pasal 1 angka 2:

"Merek Dagang adalah Merek yang digunakan pada barang diperdagangkan oleh seseorang atau beberapa orang secara bersama - sama atau badan hukum untuk membedakan dengan barang sejenis lainnya."

Dalam Pasal 1 angka 3:

"Merek Jasa adalah merek yang digunakan pada jasa yang diperdagangkan oleh seseorang atau beberapa orang secara bersama - sama atau badan hukum untuk membedakan dengan jasa sejenis lainnya."

Dalam Pasal 1 angka 4:

"Merek Kolektif adalah merek yang digunakan pada barang dan/atau jasa dengan karakteristik yang sama mengenai sifat, ciri utama, dan mutu barang atau jasa serta pengawasannya yang akan diperdagangkan oleh beberapa orang atau badan hukum secara bersama - sama untuk membedakan dengan barang dan/atau jasa sejenis lainnya."

Di dalam UU 20/2016 sendiri belum ada ruang khusus yang memberikan penjabaran secara mendetail mengenai destination branding ini sendiri. Oleh karena itu, untuk mengungkap definisi tentang apa itu destination branding maka salah satu acuan yang dapat kita gunakan adalah definisi yang diberikan oleh para sarjana dan/atau para praktisi.

Moilanen dan Rainisto memberikan pendapat bahwa, Destination Branding adalah sebuah entitas yang multidimensional dan kompleks; dimana dalam pembangunan sebuah destination branding diperlukan adanya partisipasi dari sejumlah besar kelompok dalam penciptaan dan penguatan berbagai produk dan jasa yang kemudian dikombinasikan dengan fitur fisik dari suatu daerah destinasi. ${ }^{12}$ Menurut Karen Post yang dimaksud sebagai destination branding adalah upaya untuk membuat orang tertarik untuk berkunjung dengan cara mem-brand-kan tempat/tujuan wisata. Destination Branding merupakan suatu strategi dalam memasarkan dan memperkokoh posisi potensi sebuah daerah. Melalui destination branding diharapkan terjadi perubahan konsep berfikir seseorang akan keberadaan atau posisi suatu tempat atau

12 Istanto, Freddy Handoko, dkk. "Pengembangan Potensi Wisata Berbasis Brand Destination (Studi Kasus Destinasi Wisata Budaya Di Trowulan)", Conference on Management and Behavirol Studies, Universitas Tarumanegara (2016): 464. 
lokasi termasuk didalamnya membandingkan potensi yang ada. ${ }^{13}$ Ritchie and Ritchie mengungkapkan bahwa destination branding juga dapat didefinisikan sebagai, nama, symbol, logo, word mark atau bentuk lainnya yang mampu menjadi tanda pengenal sekaligus sebagai tanda pembeda suatu destinasi wisata. ${ }^{14}$ Menurut Zanker \& Braun yang dimaksud destination branding merupakan "a network of associations in the consumer mind based on the visual, verbal, and behavior expression of a place, which is embodied through the aims, communication, values, and the general culture of the place's stakeholder and the overall place design."15 Dengan kata lain destination branding dapat diartikan sebagai sebuah upaya untuk memberikan sebuah ciri khas ataupun daya pembeda pada suatu tujuan.

Berdasarkan definisi tentang destination branding yang diberikan oleh para tokoh diatas, mengisyaratkan adanya kesamaan unsur - unsur yang dimiliki oleh merek dengan destination branding. Dimana persamaan tersebut dapat dilihat dari fungsi destination branding dan merek yaitu sebagai penanda dan pembeda dari sebuah produk dengan produk sejenis lainnya. Dengan kata lain secara implisit, destination branding telah diakui keberadaanya sebagai sebuah merek dalam UU 20/2016.

\subsection{Pendaftaran Destination Branding Sebagai Sebuah Hak Merek}

Pendaftaran merek ke Direktorat Jendral Kekayaan Intelektual (yang selanjutnya disebut sebagai Dirjen KI) merupakan salah satu cara untuk dapat melindungi keberadaan merek tersebut. ${ }^{16}$ Namun sayangnya tingkat pemahaman masyarakat Indonesia akan arti penting pendaftaran merek masih tergolong sangat rendah. Masyarakat cenderung memilih untuk langsung menjual merek tersebut ke pasaran. Dengan kata lain pengakuan terhadap merek hanya bersifat deklaratif semata. Secara prinsip perlindungan merek dalam sistem deklaratif tidak efektif dan tidak dapat memberikan sebuah kepastian hukum. Dengan kata lain perlindungan hukum terhadap merek itu cenderung lemah sehingga, merek yang hanya dideklaratifkan semata hanya akan menimbulkan praduga hukum semata.

Istilah first to use principle merupakan salah satu prinsip yang berlaku dalam sistem deklaratif. Istilah tersebut dapat diartikan bahwa hanya pengguna merek yang pertama yang dapat diberikan perlindungan hukum atas hak mereknya. Hal tersebut menyebabkan apa bila terjadi sengketa terhadap merek, diperlukan adanya pembuktian yang kuat atas siapa pengguna merek pertama kali. Pada sistem deklaratif dia yang memiliki hak atas sebuah merek adalah dia yang benar - benar menggunakan

13 Fitri, Handayani. "Aktivitas Destination Branding Pantai Lovina Bali (Studi Deskriptif Kualitatif Pada Dinas Pariwisata Kabupaten Buleleng)" Skripsi, Fakultas Ilmu Sosial dan Ilmu Politik Universitas Muhammadiyah Malang (2017): 18.

14 Rahardipha, Lalu Ageeiza. "Analisis Program Destination Branding Provinsi Nusa Tenggara Barat (Studi Deskriptif Kualitatif Terhadap Rinjani Tracking Manajement Board Pada Taman Nasional Gunung Rinjani)". Jurnal Ilmu Administrasi Bisnis, Universitas Diponegoro 5. No. 1 (2016): 3 .

15 Kladou, Stella, Mihalis Kavaratzis, Irini Rigopoulou, and Eleftheria Salonika. "The role of brand elements in destination branding." Journal of Destination Marketing $\mathcal{E}$ Management 6, no. 4 (2017): 426-435.

16 Balqis, Wizna Gania, and Budi Santoso. "Arti Penting Perlindungan Merek Terdaftar Bagi Komunitas Penghasil Produk Ekonomi Kreatif." Jurnal Pembangunan Hukum Indonesia 2, no. 2 (2020): 218. 
atau memakai merek tersebut pertama kali. ${ }^{17}$ Oleh karena tidak adanya kepastian hukum, maka sistem pendaftaran merek deklaratif ini dianggap kurang ideal dalam sebuah pendaftaran merek.

Indoneisa saat ini menganut sistem konstitutif dalam sebuah pendaftaran merek. Hal ini berarti pendaftaran kepada negara melalui badan terkait adalah bersifat mutlak untuk dapat memperoleh hak merek, sehingga apabila sebuah merek tidak atau belum didaftarkan kepada negara, maka pemiliik merek tidak dapat mengklaim merek tersebut begitu saja dan tidak mendapat hak atas merek, maka dapat dikatakan bahwa sebelum sebuah merek didaftarkan, maka merek tersebut belum diakui keberadaanya oleh hukum di Indonesia, sehingga mengakibatkan merek tersebut tidak mendapat perlindungan hukum. ${ }^{18}$ Konsep perlindungan hukum terhadap merek tersebut mengacu pada sifat hak merek yang bersifat exclusive dimana merek tersebut dapat di monopoli. ${ }^{19}$ Monopoli dalam hali ini berarti hanya pemegang merek yang berhak untuk menggunakan atau menjual maupun memberikan izin kepada pihak lain untuk menggunakan merek tersebut. Dalam sistem konstitutif pemilik merek yang mereknya telah terdaftar akan mendapatkan suatu jaminan berupa perlindungan hukum atas merek yang telah didaftarkan, perlindungan tersebut dapat berupa perlindungan hukum secara perdata seperti gugatan atas kerugian akibat penjiplakan suatu merek ataupun perlindungan hukum secara pidana seperti tuntutan hukum pidana atas suatu pelanggaran merek. ${ }^{20}$

Destination branding pada prinsipnya berpotensi mempunyai suatu nilai jual atau nilai ekonomi. Bukan tanpa alasan, apabila destination branding mampu dilaksanakan dengan benar, maka berpotensi memberikan dampak postif dalam berbagai sektor, sebagai contoh meningkatnya jumlah kunjungan wisatawan domestik maupun mancanegara ke suatu obyek wisata tertentu. ${ }^{21}$ Melalui peningkatan kunjungan wisata tersebut diharapkan mampu meningkatkan perekonomian masyarakat disekitarnya. Oleh sebab itu diperlukan adanya suatu perlindungan hukum yang jelas dan mampu untuk melindungi eksistensi dari destination branding. Upaya pendaftaran destination branding merupakan sebuah pengembangan yang timbul dari adanya bebragai jenis merek yang pengertiannya telah tercantumkan dalam pasal 1 ke 1 hingga ke 4 . Dalam UU 20/2016 memang tidak terdapat pengaturan secara eksplisit mengenai destination branding ini sendiri, namun hal tersebut bukan berarti destination branding tidak dapat didaftarkan. Adapun penyebab tidak dapat didaftarkannya sebuah merek dalam UU 20/2016 adalah sebagaimana yang tertuang dalam pasal 20, yaitu:

17 Koloay, Renuy N.S. “Fungsi Pendaftaran Merek Sebagai Upaya Menjamin Kepastian Hukum Bagi Pemegang Hak Eksklusif Atas Merek". Jurnal Hukum Unsrat, Universitas Sam Ratulangi 19. No. 2 (2011): 92.

18 Permata, Rika Ratna dan Khairunnisa, Muthia. "Perlindungan Hukum Merek Tidak Terdaftar Di Indonesia". Jurnal Opinio Juris, Direktorat Jenderal Hukum dan Perjanjian Internasional Kementerian Luar Negeri Republik Indonesia 19. (2016):84.

19 Wijaya, Kadek Yoni Vemberia, and I. Gusti Ngurah Wairocana. "Upaya Perlindungan Hukum Terhadap Pelanggaran Hak Merek." Jurnal Ilmiah Ilmu Hukum Kertha Semaya Hukum Udayana 6, no. 3 (2018).

20 Perdana, Karlina dan Pujiyono."Kelemahan Undang - Undang Merek Dalam Hal Pendaftaran Merek (Studi Atas Putusan Sengketa Merek Pierre Cardn)". Privat Law, Universitas Sebelas Maret Surakarta 5. No.2 (2017): 85.

21 Handani, Kunti. "Regional Brandig "Solo The Spirit Of Java" (Suatu Tinjauan Dari Aspek Hak Kekayaan Intelektual)". Tesis Program Magister Ilmu Hukum Program Pascasarjana, Fakultas Hukum, Universitas Diponegoro, Semarang. (2010): 5. 
"merek tidak dapat didaftar jika:

a. Bertentangan dengan ideologi negara, peraturan perundang - undangan, moralitas, agama, kesusilaan, atau ketertiban umum;

b. Sama dengan, berkaitan dengan, atau hanya menyebut barang dan/atau jasa yang dimohonkan pendaftarannya;

c. Memuat unsur yang dapat menyesatkan masyarakat tentang asal, kualitas jenis, ukuran macam, tujuan penggunaan barang dan/atau jasa yang dimohonkan pendaftarannya atau merupkana nama varietas tanaman yang dilindungi untuk barang dan/atau jasa yang sejenis;

d. Memuat keterangan yang tidak sesuai dengan kualitas manfaat, atau khasiat dari barang dan/atau jasa yang diproduksi

e. Tidak memiliki daya pembeda; dan/atau

f. Merupakan nama umum dan/atau lambing milik umum."

kemudian, sebuah merek akan ditolak pendaftarannya apabila merek tersebut mengandung unsur - unsur yang terdapat dalam pasal 21 UU 20/2016 yang dalam ayat (1) menyatakan:

"Permohonan ditolak jika Merek tersebut mempunyai persamaan pada pokoknya atau keseluruhannya dengan:

a. Merek terdaftar milik pihak lain atau dimohonkan lebih dahulu oleh pihak lain untuk barang dan/atau jasa sejenis;

b. Merek terkenal milik pihak lain untuk barang dan/atau jasa sejenis;

c. Merek terkenal milik pihak lain untuk barang dan/atau jasa tidak sejenis yang memenuhi persayaratan tertentu; atau

d. Indikasi geografis terdaftar."

Kemudian dalam ayat (2) menyatakan:

"Permohonan ditolak jika merek tersebut:

a. Merupakan atau menyerupai nama atau singkatan nama orang terkenal, foto, atau nama badan hukum yang dimiliki orang lain, kecuali atas persetujuan tertulis dari yang berhak;

b. Merupakan tituan atau menyerupai nama atau singkatan nama, bendera, lambang atau simbol atau emblem suatu negara, atau lembaga nasional maupun internasional, kecuali atas persetujuan tertulis dari pihak yang berwenang; atau

c. Merupakan tiruan atau menyerupai tanda atau cap atau stempel resmi yang digunakan oleh negara atau lembaga Pemerintah, kecuali atas persetujuan tertulis dari pihak yang berwenang."

Selanjutnya, dalam ayat (3) menyatakan:

"Permohonan ditolak jika diajukan oleh pemohon yang beritikad tidak baik."

Berdasrakan uraian diatas, maka selain hal - hal yang dinyatakan dilarang atau ditolak oleh UU 20/2016, masih memiliki peluang untuk dapat didaftrakan sebagai sebuah merek ke Dirjen KI. Dengan kata lain, meskipun belum ada pengaturan secara eksplisit yang menjelaskan mengenai destination branding, bukan berarti destination branding tidak dapat didaftarkan. Sebagaimana telah dijelaskan dalam pembahasan satu, bahwa sujatinya destination branding telah memenuhi unsur - unsur sebagai sebuah merek.

Pendaftaran destination branding dapat dilakukan secara online atau elektronik maupun secara manual dengan datang langsung sebagai pemohon ke kantor DirJen KI 
di wilayah masing - masing. Permohonan tersebut wajib memenuhi berbagai syarat administratif dan juga dokumen termasuk dokumen khusus mengenai syarat pendaftaran merek sebagaimana diatur dalam Peraturan Menteri Hukum dan HAM RI No. 67 Tahun 2016 tentang Pendaftaran Merek. Secara singkat, berikut ini merupakan digram alur pendaftaran yang dapat ditempuh:

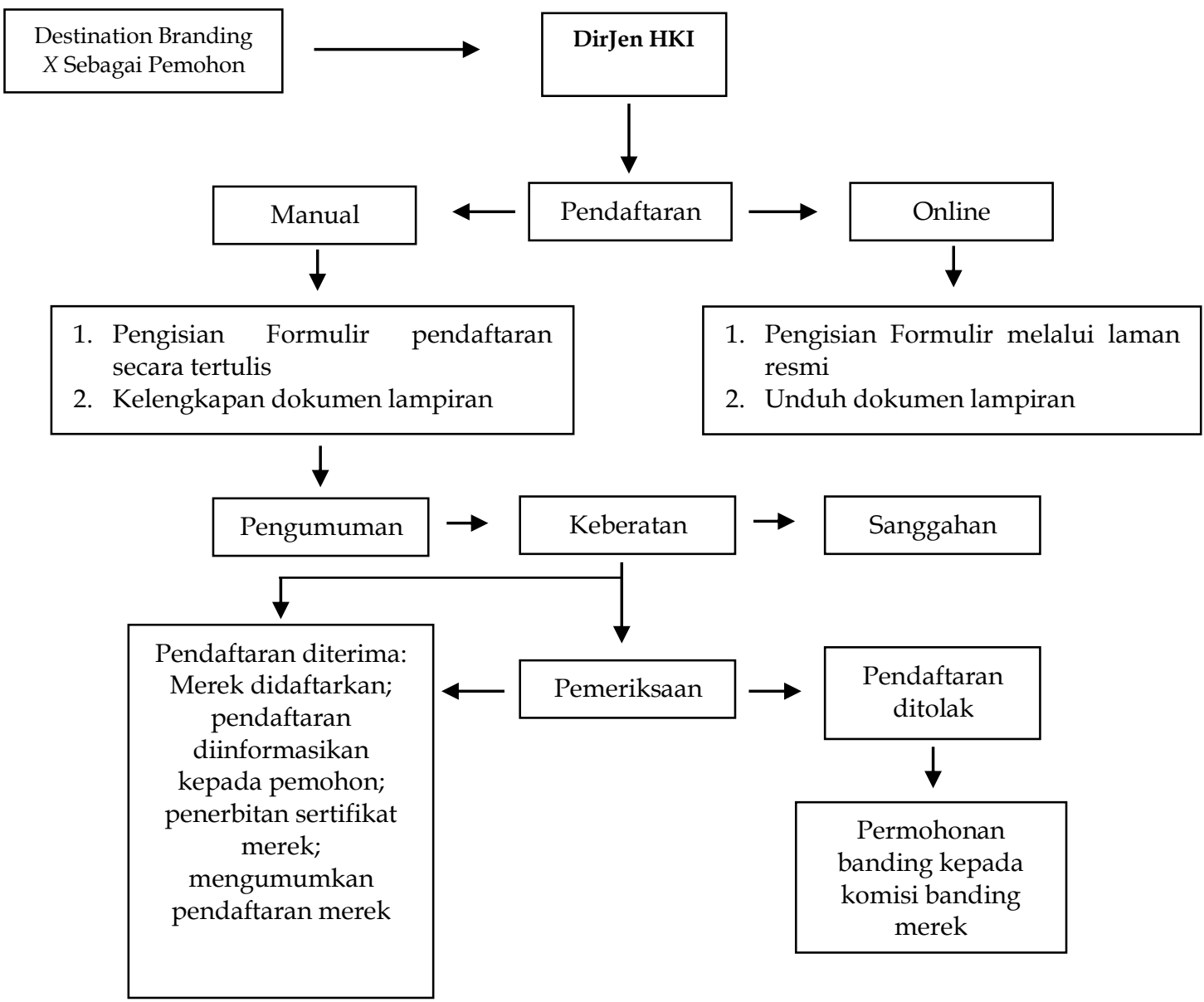

Bag. 1. Alur Pendaftaran Merek Kolektif

\section{Kesimpulan}

Dalam UU 20/2016, belum ada pengaturan yang secara khusus membahas ataupun mengatur tentang destination branding. Namun secara implisit keberadaan atau eksistensi destination branding sebagai sebuah merek telah diakomodir dalam undang undang tersebut. hal ini dapat dilihat dari adanya kesamaan unsur sebagai sebuah merek dalam UU 20/2016 dengan unsur destination branding itu sendiri. Hal tersebut menyebabkan destination branding memiliki potensi untuk dapat didaftarkan sebagai salah satu jenis hak merek ke Kantor Dirjen KI. Secara umum destination branding telah memenuhi unsur - unsur sebagai sebuah merek, selain itu selama destination branding tidak memenuhi unsur sebagaimana dimaksud dalam pasal 20 dan 21 mengenai sebuah merek yang mengakibatkan merek tidak dapat didaftarkan ataupun merek yang ditolak pendaftarannya, maka destination branding memiliki potensi untuk didaftarkan. 


\section{DAFTAR PUSTAKA}

Buku:

Jened, Rahmi, Interface Hukum Kekayaan Intelektual, and Hukum Persaingan. "RajaGrafindo Rajawali Press." (2013).

Jened, Rahmi. "Hukum Merek (Trademark Law) Dalam Era Global dan Integrasi Ekonomi." Jakarta: Kencana Prenadamedia Group (2015).

Qamar, Nurul, Muhammad Syarif, Dachran S. Busthami, M. Kamal Hidjaz, Aan Aswari, Hardianto Djanggih, and Farah Syah Rezah. Metode Penelitian Hukum (Legal Research Methods). CV. Social Politic Genius (SIGn), 2017

Sunggono, Bambang. Metodologi Artikel Hukum, Edisi 1, Cet. XVI (Jakarta, PT Raja Grafindo Persada, 2015).

\section{Skripsi, Tesis dan Disertasi}

Fitri Handayani. "Aktivitas Destination Branding Pantai Lovina Bali (Studi Deskriptif Kualitatif Pada Dinas Pariwisata Kabupaten Buleleng)" Skripsi, Fakultas Ilmu Sosial dan Ilmu Politik Universitas Muhammadiyah Malang (2017).

Handani, Kunti. "Regional Brandig "Solo The Spirit Of Java" (Suatu Tinjauan Dari Aspek Hak Kekayaan Intelektual)". Tesis Program Magister Ilmu Hukum Program Pascasarjana, Fakultas Hukum, Universitas Diponegoro, Semarang. (2010)

Harahap, Muhith Afif Syam. “Eksistensi City Branding Menurut UU No. 15 Tahun 2001 Tentang Merek (Studi Kasus "Semarang Pesona Asia" Di Kota Semarang)". Tesis Program Magister Ilmu Hukum, Universitas Diponegoro, (2008) Semarang.

\section{Jurnal Ilmiah:}

Balqis, Wizna Gania, and Budi Santoso. "Arti Penting Perlindungan Merek Terdaftar Bagi Komunitas Penghasil Produk Ekonomi Kreatif." Jurnal Pembangunan Hukum Indonesia 2, no. 2 (2020)

Betlehn, Andrew dan Samosir, Prisca Oktaviani. "Upaya Perlindungan Hukum Terhadap Merek Industri UMKM di Indonesia". Law \& Justice Jurnal, Universitas Agung Podomoro 3. No 1. (2018).

Fauzan, Siti Fridani. "City Branding Kota Bandung Melalui Bandung Tour On Bus (Studi Kasus: Badan Promosi Pariwisata Kota Bandung". E Proceeding of Management 3. No. 1 (2016)

Fitrianigsi, Dewi. "Perlindungan Hukum Hak Atas Merek Perusahaan Yang Di Merger Menurut Konsepsi Undang-undang Nomor 15 Tahun 2001 Tentang Merek." PhD diss., Legal Opinion, Universitas Tadulako (2016)

Istanto Freddy Handoko, dkk. "Pengembangan Potensi Wisata Berbasis Brand Destination (Studi Kasus Destinasi Wisata Budaya Di Trowulan)", Conference on Management and Behavirol Studies, Universitas Tarumanegara (2016).

Kladou, Stella, Mihalis Kavaratzis, Irini Rigopoulou, and Eleftheria Salonika. "The role of brand elements in destination branding." Journal of Destination Marketing $\mathcal{E}$ Management 6, no. 4 (2017).

Koloay, Renuy N.S. “Fungsi Pendaftaran Merek Sebagai Upaya Menjamin Kepastian Hukum Bagi Pemegang Hak Eksklusif Atas Merek". Jurnal Hukum Unsrat, Universitas Sam Ratulangi 19. No. 2 (2011). 
Michandani, Eka Sita. "Perancangan Destination Branding Desa Wisata Kerta Di Kecamatan Pangyangan Kabupaten Gianyar". Jurnal Destinasi Pariwisata, Fakultas Pariwisata, Universitas Udayana 7. No. 1 (2019).

Perdana, Karlina dan Pujiyono."Kelemahan Undang - Undang Merek Dalam Hal Pendaftaran Merek (Studi Atas Putusan Sengketa Merek Pierre Cardn)". Privat Law, Universitas Sebelas Maret Surakarta 5. No.2 (2017).

Permata, Rika Ratna dan Khairunnisa, Muthia. "Perlindungan Hukum Merek Tidak Terdaftar Di Indonesia". Jurnal Opinio Juris, Direktorat Jenderal Hukum dan Perjanjian Internasional Kementerian Luar Negeri Republik Indonesia 19. (2016).

Rahardipha, Lalu Ageeiza. "Analisis Program Destination Branding Provinsi Nusa Tenggara Barat (Studi Deskriptif Kualitatif Terhadap Rinjani Tracking Manajement Board Pada Taman Nasional Gunung Rinjani)". Jurnal Ilmu Administrasi Bisnis, Universitas Diponegoro 5. No. 1 (2016).

Rahman, Arif Faisal, dkk. "Aspek Hukum Regional Branding Dalam Undang Undang Nomor 15 tahun 2001 Tentang Merek dan Undang - Undang Nomor 28 Tahun 2014 Tentang Hak Cipta (Studi Kasus Jogja Istimewa Sebagai Brand Daerah Istimewa Yogyakarta)". Jurnal Artikel Hukum 2, No. 3 (2015).

Sudantra, I Ketut. "Implikasi Keputusan Meteri ATR/Kepala BPN Nomor 276/KEP19.2/X/2017 Terhadap Kedudukan Tanah Milik Desa Pakraman". Jurnal Magister Hukum Udayana (Udayana Master Law Hournal) 7, No.4 (2018).

Wijaya, Kadek Yoni Vemberia, and I. Gusti Ngurah Wairocana. "Upaya Perlindungan Hukum Terhadap Pelanggaran Hak Merek." Jurnal Ilmiah Ilmu Hukum Kertha Semaya Hukum Udayana 6, no. 3 (2018).

Yuli, Aditya. "City Branding Sebagai Strategi Pengembangan Pariwisata Ditinjau Dari Aspek Hukum Merek (Studi Kasus City Branding Daerah Istimewa Yogyakarta Sebagai Daerah Tujuan Wisata Unggulan Di Indonesia)". Jurnal Ilmiah Ilmu Hukum QISTI 5. No. 1 (2011).

\section{Situs Online:}

Merek (Def. 1) (n.d). Dalam Kamus Besar Bahasa Indonesia (KBBI) Online. Diakses melalui kbbi.web.id/merek.html,(Diakses 11 Juni 2020).

\section{Peraturan Perundang - undangan:}

Undang - Undang Nomor 20 Tahun 2016 Tentang Merek dan Indikasi Geografis. Lembar Negara Republik Indonesia Tahun 2016 Nomor 252. Tambahan Lembaran Negara Republik Indonesia Nomor 5953

Undang - Undang Nomor 32 tahun 2004 Tentang Pemerintah Daerah. Lembaran Negara Republik Indonesia Tahun 2004 Nomor 125. Tambahan Lembaran Negara Republik Indonesia Nomor 4437. 